\title{
ROBOT BURIAL
}

\author{
A moment to reflect.
}

BY H. E. ROULO

S anders stared across the scrubby hillside, resting a hand on his shovel. The horizon wavered in the heat. He sighed. Maybe he shouldn't have answered when Richie texted, but they had been chums in school. Anyway, it was too late to back out now. Sweat trickled behind his ears and dripped onto the stiff collar of his white dress shirt. He swiped at the drops.

The crunch of Richie's shovel stilled and he looked up from digging. Hazy grey dust filled the brackets around his mouth. He had hardly spoken since Sanders had arrived at their old bonfire spot, except to point to the extra shovel leaning against the twisted pine tree. A tree that, by the way, cast almost no shade.

He noticed Richie watching him with a scowl and frowned back. "What?"

Richie licked his lips and finally spoke. "Are you making fun of me in that get-up? A suit?"

"No, I just heard the word burial, and it was instinctive." Sanders closed his eyes and took a deep breath. The whole thing certainly had the grimness of a funeral. He raised the wooden shaft of his shovel out of the hole they stood in and tapped the robot's padded frame, hearing the metal clang. "I've never buried a robot before."

Richie's face turned red, like he'd finally realized how he had sounded when he called and asked Sanders to meet him in the middle of nowhere for a rush burial. Who could blame Sanders for being rattled? What a relief to confirm the body really was a powered-off jumble of foam, plastic and metal.

Richie jumped out of the hole and grabbed a sports bottle, taking a long pull of blue sugar-water. He snapped the bottle's cap back into place and nearly set the bottle on the frame of the robot but fumbled, placing it on the ground instead.

"That's a change from what we used to drink out here." Relieved they'd stopped digging, Sanders leaned on his shovel, wondering if Richie was ready to talk. Even when they were in school together he'd kept
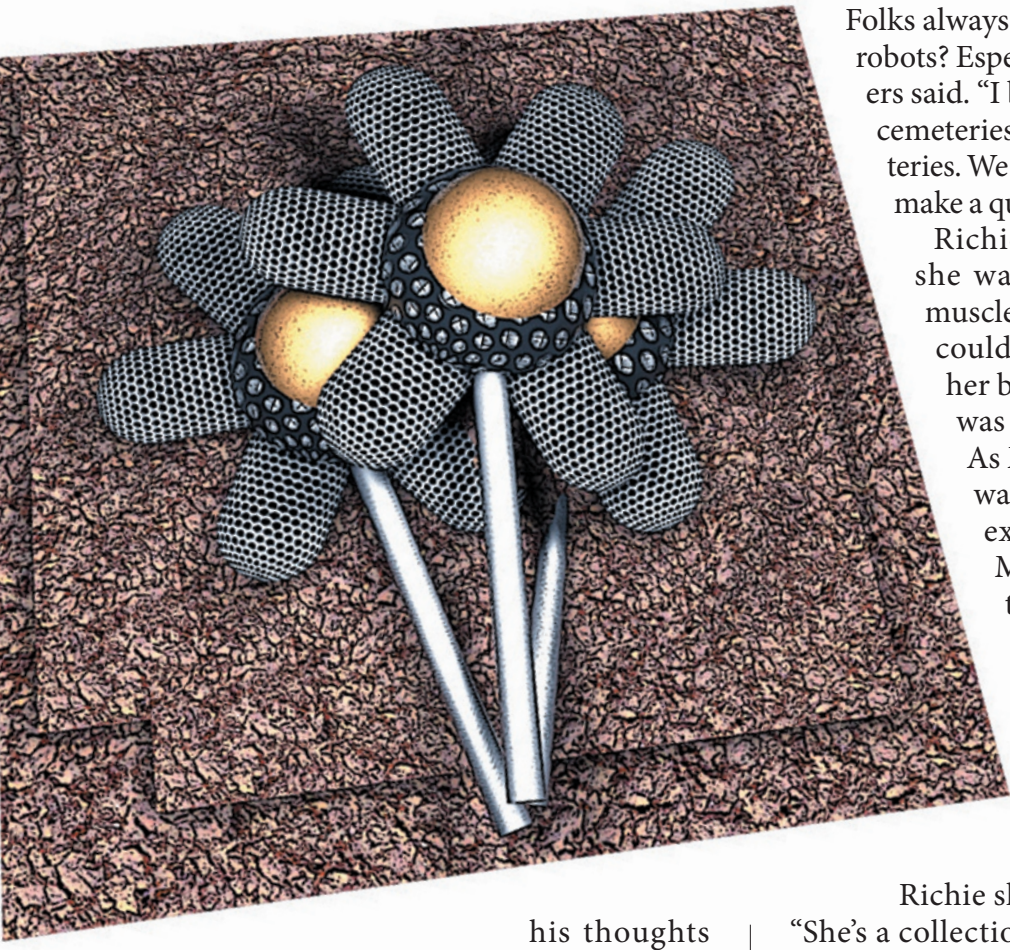

Folks always did for pets, why not for robots? Especially if they talk?" Sand"I bet we end up with robot meteries like they have pet cemeries. We should invest in one. We'd "

Richie shook his head. "No, he wasn't for me. As Mom's muscles grew weaker, the robot could be trained to take over her burdens. Pretty soon, she was taking care of Mom, too. As Mom got older, the robot was the only one who knew exactly what she wanted. Maybe I should have been there more, but I knew she'd be taken care of."

Uncertain of where this was going, Sanders leaned over to examine the robot. "She's dinged up, but are you sure she's dead?'

Richie shook himself like a dog.

his thoughts

private, and Sanders was the one who filled the silences. Some things never change. "You can still see bottles piled at the base of the tree. Looks like kids don't come out here anymore, though."

Richie examined the tree, perhaps thinking of girls he had kissed under its branches, back when they were struggling students looking for a night away from it all. $\mathrm{He}$ mumbled: "Those were good times."

Not like today, seemed to go unsaid.

"Maybe the suit was silly," Sanders admitted. "It's not like I expected we'd meet at a cemetery. What graveyard is going to allow a robot to be buried there? And it's not like the robot was religious, am I right?"

Richie chuckled.

Encouraged, Sanders said: "She was a household robot, right? They're different now, but I remember one like that from when I was little."

"My folks were always early adopters. The robot was bought to assist my mother with chores even before her diagnosis."

"Gotcha. Old story. I suppose she ended up being a nanny to you? You spent more time with her than your parents?"
Follow Futures: @NatureFutures

f go.nature.com/mtoodm $\rightarrow$ NATURE.COM
Richie's lips tightened.

"Even with true AI outlawed, it's easy to form attachments.
"She's a collection of Mom's quirks, and now that Mom's dead, she doesn't have a purpose. Too old to retrain, and too beatup to sell. I called several dealers. They said they would buy the parts." With his left hand, he reached out to the prone robot and folded flesh-toned padding into place. "But after everything she's done, it would be like selling my sister for parts. She didn't just do the things my parents didn't want to do, she did what I didn't want to do, too. Mom and I both got to keep nearly normal lives for a long time after she was disabled ... I completed my degree because of her.

"I kept her running for a while, but I don't want her to be the part of my mother that lasts the longest. It's time."

Sanders was nodding. "So, we bury the robot."

"Yeah," Richie picked up his shovel. "But I'll have to run back to my house for something."

Reluctantly, Sanders picked up his shovel. "What's that?"

"My good suit." -

H. E. Roulo lives in Seattle. She has released a dozen short stories, including 'Immeasurable' in Nature previously. She recently released the first book in her Plague Master series. Find more at www.heroulo.com. 